\title{
MANAJEMEN PRASARANA UNTUK ANAK DISABILITAS DI PENDIDIKAN INKLUSIF
}

\author{
Assyakhirah Nur Ridha \\ Program Studi Pendidikan Bahasa Inggris, Fakultas Keguruan dan Ilmu Pendidikan \\ Universitas Lambung Mangkurat, Banjarmasin \\ Email: assyahirahnura@gmail.com
}

\begin{abstract}
The purpose of this literature study journal is to collect and find out and discuss previous research on infrastructure management for children with disabilities in inclusive education. This research uses a literature study approach by collecting information and data in depth through books, journals, and other references, as well as relevant previous research results, to obtain answers and theoretical basis for the problems to be studied and library research can simultaneously utilize library sources. For research data sources, without doing field research. The results showed that there were several researchers who stated that there was still a lack of infrastructure management for children with disabilities, which affected learning. Some researchers say the success of infrastructure management is supported by the contribution of readiness in terms of facilities and infrastructure to implement an inclusive education service system.
\end{abstract}

Keywords: Manajemen, inclusive, infrastructure, education

ABSTRAK: Tujuan dari jurnal studi kepustakaan ini adalah untuk mengumpulkan dan mengetahui serta membahas penelitian terdahulu tentang manajemen prasarana untuk anak disabilitas di pendidikan inklusif. Penelitian ini menggunakan metode pendekatan studi kepustakaan dengan cara pengumpulan informasi dan data secara mendalam melalui buku, jurnal, dan referensi lainnya, serta hasil penelitian sebelumnya yang relevan, untuk mendapatkan jawaban dan landasan teori mengenai masalah yang akan diteliti dan penelitian kepustakaan dapat sekaligus memanfaatkan sumber kepustakaan untuk sumber data penelitiannya, tanpa melakukan penelitian lapangan. Hasil penelitian menunjukkan ada beberapa penliti yang menyebutkan bahwa masih kurangnya manajemen prasarana untuk anak disabilitas sehingga mempengaruhi pembelajaran. Beberapa peneliti mengatakan keberhasilan manajemen prasarana ini didukung oleh kontribusi kesiapan dalam hal sarana dan prasarana untuk melaksanakan system layanan pendidikan inklusif.

Kata kunci: Manajemen, Inklusif, Prasarana, Pendidikan 


\section{Pendahuluan}

Undang-Undang Republik Indonesia No. 20 tahun 2003 tentang system pendidikan Nasional "Setiap satuan pendidikan formal dan non formal menyediakan sarana dan prasarana yang memenuhi keperluan pendidikan sesuai degan pertumbuhan dan perkembangan potensi fisik, kecerdasan intelektual sosial, emosional, dan kewajiban peserta didik". Serta PP RI No. 19 tahun 2005 tentang Standar Nasional Pendidikan Bab VII pasal 42 ayat 1 dan 2;

1. Setiap satuan pendidikan wajib memiliki sarana yang meliputi: perabot, peralatan pendidikan, buku dan sumber belajar lainnya, bahan habis pakai serta perlengkapan yang diperlukan untuk menunjang proses pembelajaran yang teratur dan berkelanjutan.

2. Dari setiap satuan pendidikan meliputi: lahan, ruang kelas, ruang pimpinan, ruang guru, ruang perpustakaan, ruang laboratorium, kantin, tempat berolahraga dan tempat beribadah, tempat bermain, tempat berekreasi, dan ruang tempat lain yang diperlukan untuk menunjang proses pembelajaran yang teratur dan berkelanjutan.

Pendidikan berkualitas tentunya perlu memiliki standar-standar tertentu agar pelaksanaan pembelajaran tidak menyimpang dari tujuan yang sudah ditetapkan. Pendidikan menjadi salah satu landasan utama dalam mencetak generasi baru yang unggul. Pendidikan nasional berfungsi mengembangkan kemampuan dan membentuk watak serta peradaban bangsa yang bermartabat dalam rangka mencerdaskan kehidupan bangsa (UU No. 20 Tahun 2003. Sistem Pendidikan Nasional). Pendidikan yang bermutu diawali dengan suasana belajar yang nyaman dan hangat. Untuk dari itu, pentingnya meningkatkan kualitas pendidikan. Salah satu solusi tersebut yaitu adalah diperbaikinya sistem manajemen pendidikan di satuan-satuan pendidikan (Wati, 2014). Seperti manajemen prasarana.

Manajemen prasarana merupakan mekanisme kerjasama yang terkait dengan semua peralatan dan penggunaan semua peralatan pendidikan sehingga lebih efektif dan efisien. Mendapatkan layanan pendidikan yang bermutu didapatkan oleh semua siswa tidak terkecuali, anak berkebutuhan khusus (disabilitas) di pendidikan inklusif. Menurut Suparno (2007) anak berkebutuhan khusus adalah anak-anak yang menyandang kecacatan tertentu atau disable children secara fisik, mental dan emosional maupun yang mempunyai kebutuhan khusus dalam pendidikannya. Perserikatan Bangsa-Bangsa tentang Hak Anak (UNCRC, 1989) menyatakan bahwa pendidikan dasar wajib dan aksesibilitas informasi pendidikan \& kejuruan dan bimbingan untuk semua anak. Pasal 23 mengikat negara untuk memastikan bahwa semua anak penyandang disabilitas menikmati kehidupan yang layak dan penuh. Pada prinsipnya penyelenggaraan pendidikan dilaksanakan secara demokratis dan adil, tanpa diskriminasi dan menjunjung tinggi hak asasi manusia demi kebhinekaan bangsa. 
Standar nasional pendidikan yang mengikuti menyelenggarakan pendidikan inklusif, harus menuntut adanya modifikasi terhadap indikator-indikator pendidikan agar pembelajaran inklusif dapat berkembang dengan baik. Salah satu indikator ini adalah sarana dan prasarana.

Kartikasari (2014) mengemukakan bahwa pendidikan inklusif memerlukan beberapa sarana dan prasarana khusus untuk memperlancar proses pembelajaran khususnya bagi anak yang memiliki kebutuhan khusus. Alat - alat tersebut seperti buku berhuruf "braille", keramik timbul, alat terapi motorik, komputer dengan aplikasi khusus, ruangan khusus, dan lain sebagainya. Manajemen berasal dari kata bahasa Inggris yaitu management, yang diterjemahkan pula menjadi pengelolaan, berarti proses penggunaan sumber daya secara efektif untuk mencapai sasaran. Sarana pendidikan pada dasarnya adalah segala harta atau fasilitas untuk mempermudah dan memperlancar proses pendidikan dan pengajaran, baik langsung maupun tidak langsung. Sarana pendidikan dapat dikelompokkan menjadi beberapa kelompok yaitu tanah, gedung, peralatan dan perabot sekolah.

Sarana dan prasarana di sekolah penyelenggara pendidikan inklusif harus dapat diakses oleh semua peserta didik, terutama peserta didik yang memiliki hambatan penglihatan, hambatan fisik dan fungsi motorik.

\section{Metode}

Metode yang digunakan dalam penulisan artikel ini adalah pendekatan studi kepustakaan. Menurut R. Poppy Yaniawati (2014), Penelitian kepustakaan merupakan suatu jenis penelitian yang digunakan dalam pengumpulan informasi dan data secara mendalam melalui berbagai literatur, buku, catatan, majalah, referensi lainnya, serta hasil penelitian sebelumnya yang relevan, untuk mendapatkan jawaban dan landasan teori mengenai masalah yang akan diteliti dan penelitian kepustakaan dapat sekaligus memanfaatkan sumber kepustakaan untuk sumber data penelitiannya, tanpa melakukan penelitian lapangan. Data yang digunakan dalam artikel ini adalah data yang diperoleh dari jurnal, buku dan beberapa sumber lainnya. Tentunya instrument pada pendekatan studi kepustakaan ini adalah peneliti sendiri (human instrument).

\section{Hasil dan Pembahasan}

Bafadal (2003) mengatakan prasarana pendidikan diklasifikasikan menjadi dua; pertama, prasarana yang secara langsung digunakan untuk proses belajar mengajar seperti ruang teori, ruang perpustakaan, ruang pratik keterampilan dan ruang laboratorium. Kedua, prasarana yang keberadaannya tidak digunakan untuk proses belajar mengajar seperti ruang kantor, kantin, masjid, tanah, jalan menuju lembaga, kamar kecil, ruang UKS, ruang guru, ruang kepala lembaga dan ruang parkir kendaraan. Prasarana pendidikan adalah semua perangkat kelengkapan dasar yang secara tidak langsung menunjang pelaksanaan proses pendidikan sekolah menurut 
Drs. Daryanto dan Drs. Mohammad Farid, MT (2013:106). Contoh dari prasarana pendidikan seperti ruang teori, ruang perpustakaan, ruang labor, WC, kantin sekolah, ruang UKS, lapangan sekolah dan lain sebagainya.

Manajemen prasarana merupakan salah satu solusi keberhasilan penyelenggara pendidikan inklusif. Sarana dan prasarana yang memadai perlu diberikan kepada sekolah yang menyelenggarakan pendidikan inklusif agar siswa dapat memahami pembelajaran secara efektif dan efisien (Imaniah \& Fitria, 2018). Prasarana di sekolah penyelenggara pendidikan inklusif harus dapat di akses oleh semua peserta didik, terutama peserta didik yang memiliki hambatan penglihatan, hambatan fisik dan fungsi motoric. Karena hal ini berdampak pada anak-anak yang memang kurang mandiri dalam bermobilitas di lingkungan sekolah sehingga aktifitas yang dilakukan harus bergantung pada orang-orang disekitarnya. Maksum (2003) mengemukakan bahwa semakin banyak sarana yang tersedia, semakin mudah menggunakan dan memanfaatkannya untuk suatu kegiatan.

Diketahui dari beberapa peneliti sebelumnya, aksesibilitas peserta didik inklusif masih sangat rendah, bangunan masih naik turun seperti tanjakan dan tangga, belum ada pembangunan toilet khusus, lantai belum di design untuk siswa tunantera. Selain itu juga ditemukan dibeberapa sekolah belum memiliki alat asesmen khusus seperti audiometer asesmen untuk tunarungu dan untuk asesmen tunanetra. Dengan kata lain aksesibilitas ini dapat dibagi menjadi dua; aksesibilitas fisik dan non-fisik.

1. Aksesibilitas fisik

Permen PU No. 30 tahun 2006 tentang Pedoman Teknis Fasilitas Aksesibilitas Pada Bangunan Gedung dan Lingkungan. Ini mengatur persyaratan teknis fasilitas dan aksesibilitas pada bangunan gedung dan lingkungan. Tentunya termasuk ruang terbuka dan penghijauan yang dipergunakan dan/atau dikunjungi orang, khusunya agar mudah diakses oleh lansia dan penyandang disabilitas. Dan disebutkan pedoman teknis tersebut dibuat untuk memenuhi beberapa prinsip aksesibilitas, yakni "keselamatan", "kemudahan", "kegunaan", dan "kemandirian";

1. Keselamatan, yaitu setiap bangunan yang bersifat umum dalam suatu lingkungan terbangun, harus memperhatikan keselamatan bagi semua orang;

2. Kemudahan, yaitu setiap orang dapat mencapai semua tempat atau bangunan yang bersifat umum dalam suatu lingkungan;

3. Kegunaan, yaitu setiap orang harus dapat mempergunakan semua tempat atau bangunan yang bersifat umum dalam suatu lingkungan;

4. Kemandirian, yaitu setiap orang harus bisa mencapai, masuk dan mempergunakan semua tempat atau bangunan yang bersifat umum dalam suatu lingkungan dengan tanpa membutuhkan bantuan orang lain. Juga dalam Permen PU ini mengatur komponen-komponen bangunan dan lingkungan berikut: a) ukuran dasar ruang; b) jalur pedestrian; c) jalur pemandu; d) area parkir; 
e) pintu; f) ram; g) tangga; h) lift (stairway lift); j) toilet; k) pancuran; 1) wastafel; m) telepon; n) perlengkapan dan peralatan control; o) perabot; dan p) rambu dan marka.

\section{Aksesibilitas Non-fisik}

Aksesibilitas non-fisik biasanya berkaitan dengan bagaimana informasi, komunikasi dan teknologi yang daopat digunakan atau dipahami penyandang disabilitas khususnya dipendidikan inklusif. Hal ini terkait dengan bagaimana kebutuhan penyandang disabilitas, yakni, pertama, apakah informasi yang kita buat dapat dipahami oleh penyandang disabilitas rungu, low vision/ netra atau kesulitan belajar (learning disability). Kedua, pentingnya memodifikasi bentuk media informasi dalam format tertentu, misalnya mencetak dalam font yang besar agar dapat digunakan oleh individu low vision. Ketiga, memberi layanan "communication support", dengan tujuan penyandang disabilitas lebih memahami informasi yang ada, contohnya untuk membacakan teks tertentu untuk tunanetra, menggunakan catatan atau tulisan ketika berkomunikasi dengan penyandang rungu-wicara dan sebagainya.

Selain itu ada peneliti yang menyebutkan keberhasilan pembelajaran di sekolah dasar inklusif untuk satu wilayah dapat dilihat dari dukungan kontribusi kesiapan dalam hal sarana dan prasarana untuk melaksanakan system layanan pendidikan inklusif. Amka (2019) menyebutkan, (a) sekolah memiliki ruang sumber (kelas khusus) yang dilengkapi dengan peralatan, media dan sumber belajar yang memadai, (b) bangunan sekolah telah dilengkapi dengan fasilitas khusus yang aksesibel bagi ABK, (c) sekolah memiliki sarana pendukung mobilitas ABK sesuai dengan jenis kelaminnya, (d) sekolah menyediakan kamar mandi atau toilet yang aksesibel bagi pengguna kursi roda, (e) sekolah memilki alat bantu belajar yang memadai sesuai kebutuhan ABK, (f) sekolah menyediakan tongkat putih bagi tunanetra, (h) sekolah menyediakan alat bantu menulis Braille.

Tentunya manajemen prasarana akan berjalan dengan baik jika banyak pihak yang mendukung manajemen seperti, kepala sekolah, yayasan dan orang tua. Dengan banyaknya dukungan, maka pelaksanaan manajemen akan menjadi lebih baik.

\section{Kesimpulan}

Pendidikan menjadi salah satu landasan utama dalam mencetak generasi baru yang unggul. Untuk dari itu, pentingnya meningkatkan kualitas pendidikan. Salah satu solusi tersebut yaitu adalah diperbaikinya sistem manajemen pendidikan di satuan-satuan pendidikan (Wati, 2014). Seperti manajemen prasarana. Manajemen prasarana merupakan mekanisme kerjasama yang terkait dengan semua peralatan dan penggunaan semua peralatan pendidikan sehingga lebih efektif dan efisien. Mendapatkan layanan pendidikan yang bermutu didapatkan oleh semua siswa tidak terkecuali, anak berkebutuhan khusus (disabilitas) di pendidikan inklusif. Sarana dan prasarana di sekolah penyelenggara pendidikan inklusif harus dapat diakses oleh semua peserta 
didik, terutama peserta didik yang memiliki hambatan penglihatan, hambatan fisik dan fungsi motorik. Diketahui dari beberapa peneliti sebelumnya, aksesibilitas peserta didik inklusif masih sangat rendah, bangunan masih naik turun seperti tanjakan dan tangga, belum ada pembangunan toilet khusus, lantai belum di design untuk siswa tunantera.

Selain itu juga ditemukan dibeberapa sekolah belum memiliki alat asesmen khusus seperti audiometer asesmen untuk tunarungu dan untuk asesmen tunanetra. Dengan kata lain aksesibilitas ini dapat dibagi menjadi dua; aksesibilitas fisik dan non-fisik. Selain itu ada peneliti yang menyebutkan keberhasilan pembelajaran di sekolah dasar inklusif untuk satu wilayah dapat dilihat dari dukungan kontribusi kesiapan dalam hal sarana dan prasarana untuk melaksanakan system layanan pendidikan inklusif. Manajemen prasarana yang memadai akan memudahkan dalam pelaksanaan pendidikan disekolah, khususnya untuk anak disabilitas di pendidikan inklusif. Pembelajaran akan lebih mudah ketika manajemen prasarana nya berjalan dengan baik dan sesuai.

\section{Referensi}

Mustafa, M. A. (2018). Manajemen Sarana Pendidikan Pada Sekolah Anak Berkebutuhan Khusus Di Sdlb Ytc Kutablang Kabupaten Bireuen. Jurnal Administrasi Pendidikan: Program Pascasarjana Unsyiah, 6(1).

Amka, A. (2020). Manajemen Sarana Sekolah Penyelenggara Inklusi.

Herviani, V. K. (2019, December). Evaluation Of Teacher And School Infrastructure Inclusive Education In Bontang. In 3rd International Conference on Special Education (ICSE 2019). Atlantis Press.

Megasari, R. (2020). Peningkatan pengelolaan sarana dan prasarana pendidikan untuk meningkatan kualitas pembelajaran di SMPN 5 Bukittinggi. Jurnal Bahana Manajemen Pendidikan, 2(1), 636-648.

Mete, P. (2020). The views of students in an inclusive classroom environment in high school on the course learning process. Elementary Education Online, 19(2), 552-564.

ULM, P. K. (2020). Manajemen Sarana Dan Prasarana Pembelajaran Untuk Anak Berkebutuhan Khusus di SDN Inklusi Semangat Dalam 2 Kabupaten Batola. 
Amka, D. E. K. (2019). The Level of Support For Successful Learning in Inclusive Primary School in Banjarmasin. Journal of ICSAR; Volume, 3(2), 1-8.

Apolinali, P. (2007). The impact of infrastructure on inclusive education. A case of Pugu Secondary School (Doctoral dissertation, University of Dar es Salaam).

Daroni, G. A., Solihat, G., \& Salim, A. (2018). Manajemen Pendidikan Khusus di Sekolah Luar Biasa Untuk Anak Autis. Kelola: Jurnal Manajemen Pendidikan, 5(2), 196-204.

Syafi'ie, M. (2014). Pemenuhan aksesibilitas bagi penyandang disabilitas. Inklusi, 1(2), 269-308.

Kartikasari, O. D. (2014). Manajemen Sarana dan Prasarana Pembelajaran Di SD Tumbuh 1 Yogyakarta. Skripsi. Universitas Negeri Yogyakarta.

Peraturan Pemerintah, R. I. (2005). No. 19 Tahun 2005. Tentang standar nasional pendidikan

Wartomo, W. (2016). Pelaksanaan Model Pendidikan inklusif di sekolah Wilayah di yogyakarta. Mukaddimah: Jurnal Studi Islam, 1(1), 197-220. 